\title{
Risk Management: Impact Of The Macroeconomic Variables In The Stock Market Sectors
}

\author{
Juan Carlos Bribiesca Aguirre, (E-mail: juan_carlos_bribiesca@mastercard.com), Universidad Anáhuac, México Sur, Mexico
}

\begin{abstract}
This research enhances the importance of the risk management and decision analysis, specifically addresses the impacts of macroeconomic variables in the stock market. The theoretical framework covers the evolution of investment analysis tools from portfolio management to recent financial theories applied to the Mexican Stock Market. In one of the recent works, Francisco Lopez, a Mexican researcher discovered evidences of different impacts of macroeconomic variables in the Mexican stock exchange market at a productive sector level. The scope of this work is to expand and continue to exploring these findings. The strategy is to apply statistical analysis over longitudinal data to identify and understand such impacts to the Mexican stock market. Volatility and risk impacts in the market create a challenging environment to the decision makers; analysis models could be enhanced to include these macroeconomic variables and assess impacts on specific productive sectors; the application of this knowledge will provide direct benefits to the market, the productive sectors and to the economy participants.
\end{abstract}

\section{INTRODUCTION}

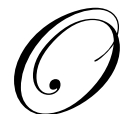

ne of the main financial targets of the companies is to maximize the investment value; usually decisions should be taken in complex environments. There are many factors involved in a decision process that need to be considered, e.g. the companies face different risk levels, inconsistent information availability, variable economic environment and even the personal risk aversion of a decision maker has a very important influence.

Risk is one of the factors that are considered when investment decisions are made. We can think of risk as the measure of the probability to obtain different returns that the expected ones or even negative results from a particular investment.

Every financial instrument (considered as an investment alternative) carries an associated risk level; to mitigate this, the companies usually maintain portfolios with a mix of instruments depending on risk and liquidity. Besides the intrinsic risk associated with every instrument, the market risk is always present. That is why it is very important to assess the risk contribution of every instrument that is included in the portfolio considering always the economy as its environment.

Financial Institutions and Treasury Departments of several companies maintain investment portfolios which its valuation depends on the exogenous economy variables such as interest and exchange rates.

Managers and regulatory entities explain the magnitude and possible variations on the portfolios value across the time establishing a risk market measure.

The contribution to the portfolio risk of each selected investment instrument, can be measured by observing the sensitivity to the market variations, it is then possible to apply this important measure as a relevant factor in the investment decision analysis process. 


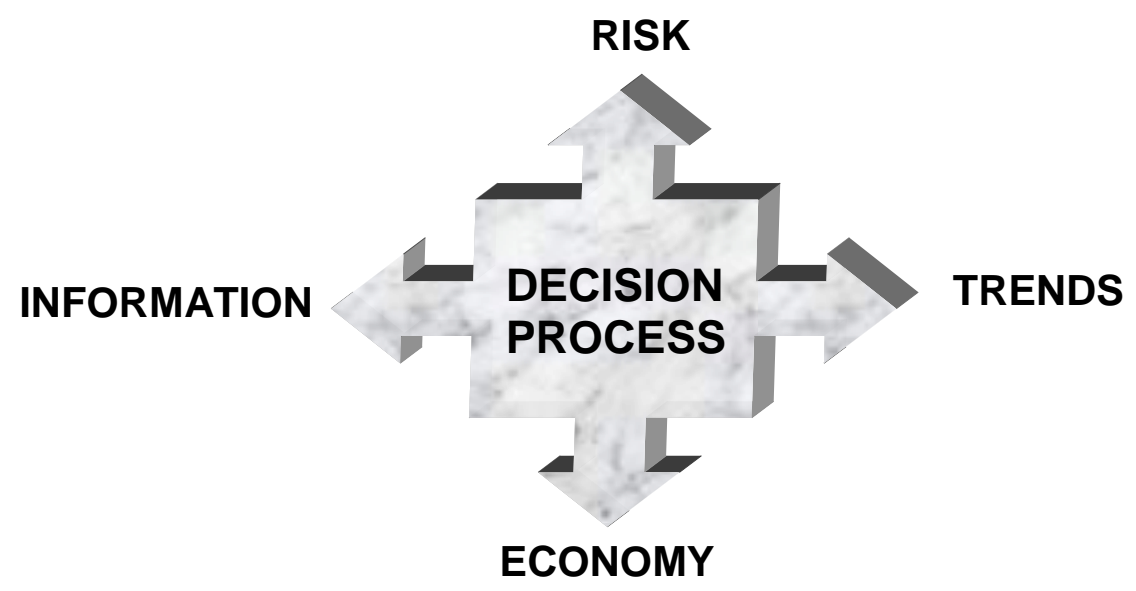

The economics data not only serve to the investors to read the economy, it influences stock market negotiations and Central Bank monetary policies, according Siegel it also has influence in the stocks prices. Parness uses this example: to some stock traders the stocks prices behavior seems to be as mysterious and unpredictable like the weather without neither meteorologists nor satellite pictures.

Some of the macroeconomic factors impact the economy at a country level; however, these factors are not easy to identify, therefore create confusion to the investors when they try to asses possible losses. Due to the volatility there is no way to predict the portfolio performance; some investors take decisions based on historical data of good returns in the stock market, they also try to diversify the investment to reduce risk.

\section{PORTFOLIO DIVERSIFICATION}

Portfolio diversification is not a new concept, it has been applied to reduce risk and to minimize stock price variations. In 1738 Bernoulli recommended to separate the exposed goods in small portions to avoid a generalized risk. With the 1938 book "Value of Investment Theory", John Bur Williams inspired Harry Markowitz to write in 1952 the basics of the portfolio theory.

The idea was that it is possible to reduce the risk of an investment using a well diversified portfolio and at the same time maintain the expected returns. Markowitz and others dedicated years to develop mathematical models to support investors' decision process.

\section{CAPM (Capital Asset Pricing Model)}

A study line was the CAPM (Capital Asset Pricing Model) developed by Sharpe in 1963-64, this was the basis to asset valuation. Lintner in 1965 and Fama in 1970 worked to optimize the proportion of the investment using risk data. In 1993, Fama considered the existence of a common factor that impacts all asset returns. market.

A way to perform risk valuation is to apply the CAPM to analyze time series price variations with respect to

\section{APT (Arbitrage Pricing Theory)}

The CAPM as a method to value assets has been very controversial; this favored the creation of new methods like the APT (Arbitrage Pricing Theory) that was designed by Ross in 1976. The APT considers that the return on asset investments is a result of various risk factors and not only the relationship with the market prices. 
Ross, Roll and Chen in 1986 continued working in establish relationships between macroeconomic variables and be able to identify those that are part of the systemic risk. They analyzed the industrial production, inflation, risk premiums, interest rate, stock market index, consumption index, and oil prices. Using this as a basis, in 1997 there was identified that to the north-American market the factors that explain the return on asset investment are the investment confidence, interest rates, inflation, industrial activity and stock market index.

In 1997 Groenewold and Fraser tested the Arbitrage Pricing Theory (APT) in the Australian market and determined that inflation index was the factor with more influence in the stock prices. They also found additional factors that influenced in different magnitude depending on the analyzed period: short term interest rate, monetary base growth.

\section{MEXICO CASE}

In Mexico, Vazquez applied the Arbitrage Pricing Theory (APT) to a large time series in 2000. In 2002 determined that the systemic risk is mostly explained by the changes in the monetary base, inflation rates, oil prices, market index and changes in the international reserves.

In the Mexican University (UNAM) publication: Accounting and Management Magazine 206 in 2002 there was a release of an article regarding the APT applied for portfolio selection in the Mexican stock market written by Francisco López Herrera.

This investigation shows the initial tests to explain the systemic risk with macroeconomic factors and conclude that the APT offers an important theoretical framework to explain the relation return-risk of stock assets in Mexico.

Although it was not part of the objectives on this investigation, in the process they found evidences that show common risk factors for stocks that are part to the same economy sector.

\section{RESEARCH PROPOSAL}

The on-going investigation pursuits to identify the impacts that the macroeconomic variables provoke in the performance on the relation risk-return at a sector level in the Mexico stock market.

The objective of this research is that the decision making process in terms of investment could be made with better confidence levels. If we have a way to identify and validate the effects of some the macroeconomic variables in the stock market, it could be possible to establish more accurate measure models.

Investment decisions based on more information elements and better risk assessment models will encourage investors to allocate resources in specific productive sectors, which will bring benefits to companies, stockholders and employees.

\section{HYPOTHESIS 1}

The main hypothesis is:

There are macroeconomic variables that cause direct and particular impacts in the Mexican stock exchange market at a sector level. 


\author{
Independent Variables* \\ Monetary base changes \\ Inflation \\ Oil prices \\ Market Index \\ International Reserves
}

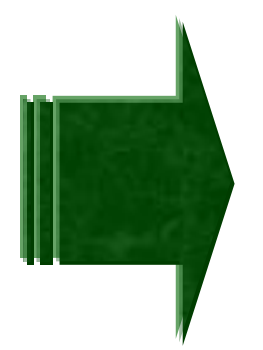

SECTORS**

Extractive Industry

Transformation

Construction

Retail

Transport and Communications

Services

Miscellaneous

* Macroeconomic variables identified by Vazquez (2001).

** Sectors according Mexican Stock Exchange classification.

\section{HYPOTHESIS 2}

The impact of the macroeconomic variables in the sector performance has permanent implications.

The idea is to evaluate correlation data in different time ranges to be able to identify transit patterns or permanent effects on the risk-return relation.

\section{RESEARCH DESIGN}

The research will be supported with an exploratory phase that will turn into a correlation stage, it will also be causal with intervenient variables, the relation cause-effect between dependent variables (macroeconomic variables) and independent variables (sector portfolio returns) will also be analyzed.

The exploratory phase will present the evolution of the risk-return relationship studies until it reaches the conclusion of recent research analysis. This will be the starting point of the research hypothesis. It will also serve to place the theoretical framework. The following diagram shows the research design:

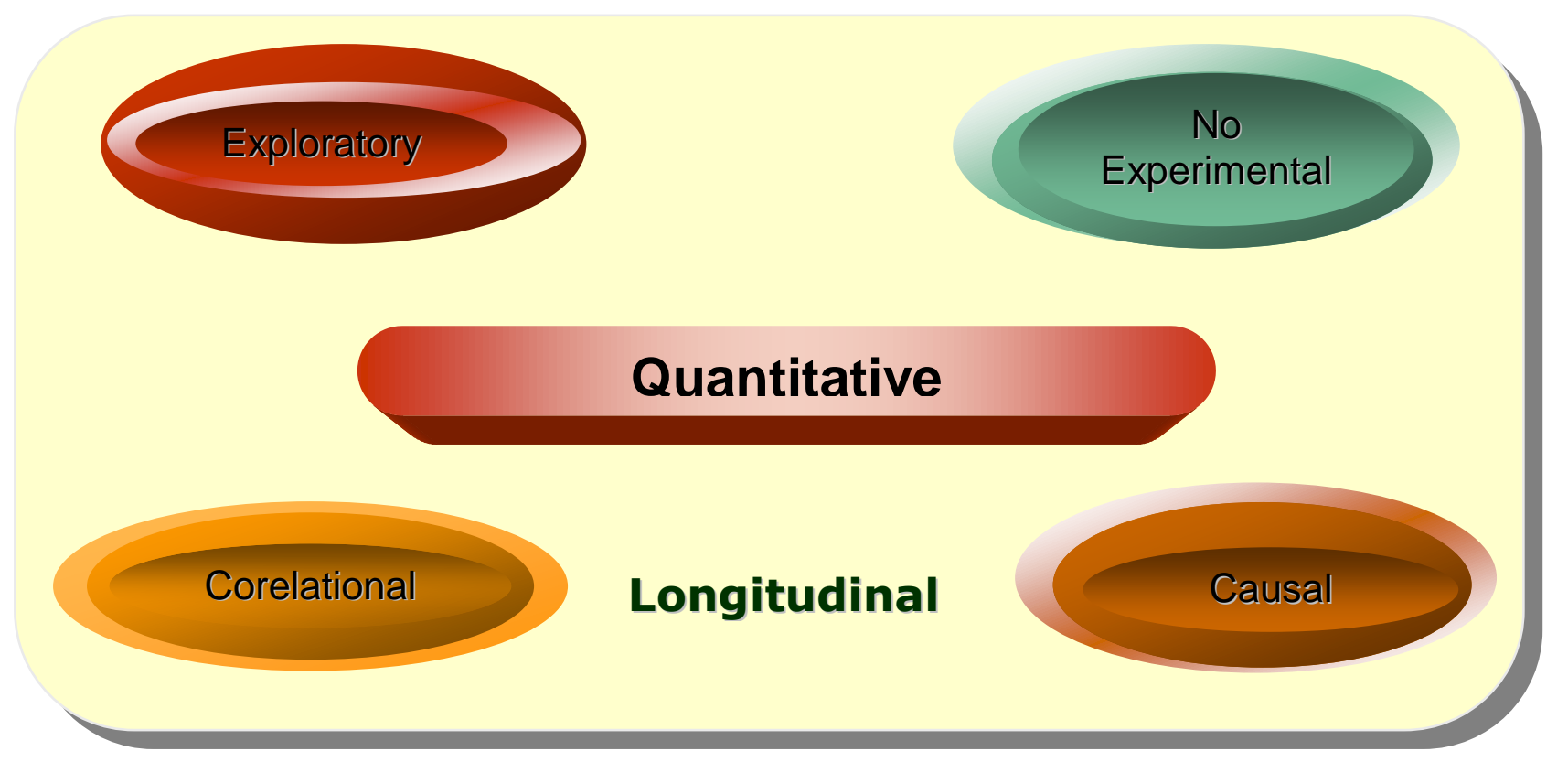




\section{RESEARCH FOCUS}

There will be a qualitative validation using a non-experimental design, longitudinal. Then, based on the results, we can proceed to evaluate and perform the hypothesis test with a multivariate correlation to show causality.

The research will end with a report on the observed effects of the macroeconomic sectors of the stock exchange market and to define the seasonal character of the impacts.

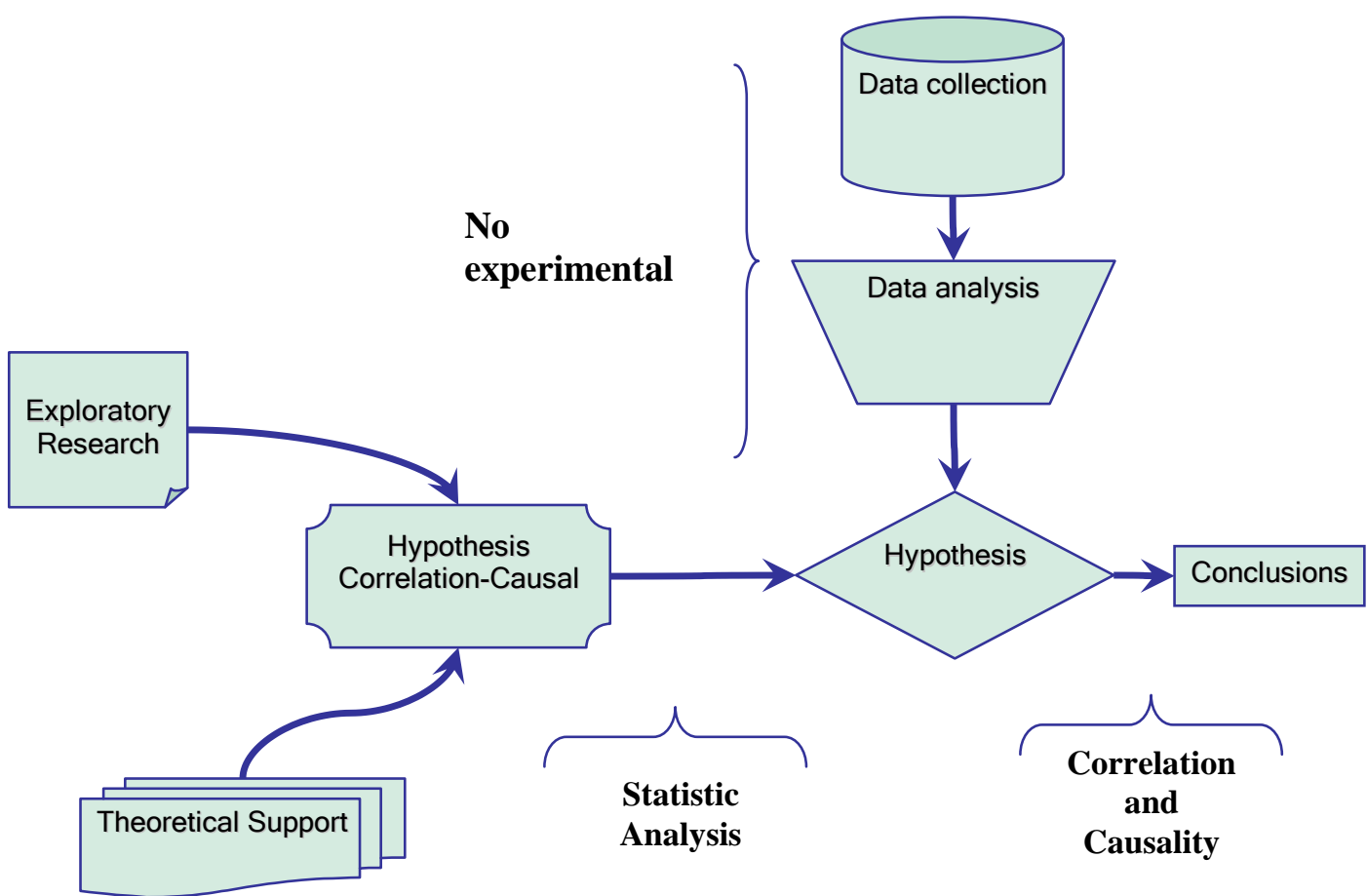

\section{DATA ANALYSIS}

The main piece of this research is the correlation model that will determine the way macroeconomic variables affect the market. The following techniques will be analyzed to define witch can provide the best results.

- $\quad$ AutoRegressive Conditional Heteroskedasticity (ARCH).

- $\quad$ Generalized ARCH (GARCH).

- $\quad$ Exponential GARCH (EGARCH).

- $\quad$ Glosten, Jagannathan, y Runkle (GJR).

- $\quad$ Asymmetric Power ARCH (APARCH). 


\section{RESEARCH PROCESS}

The process will follow these steps:

- $\quad$ Identify stock market sectors and define the criteria to select stocks.

- Identify macroeconomic factors and information sources.

- $\quad$ Define the analysis model.

- $\quad$ Setup portfolios in each identified sector.

- $\quad$ Perform the longitudinal analysis with quarterly reports

- $\quad$ Test the hypothesis with a correlation model

- $\quad$ Research Conclusion

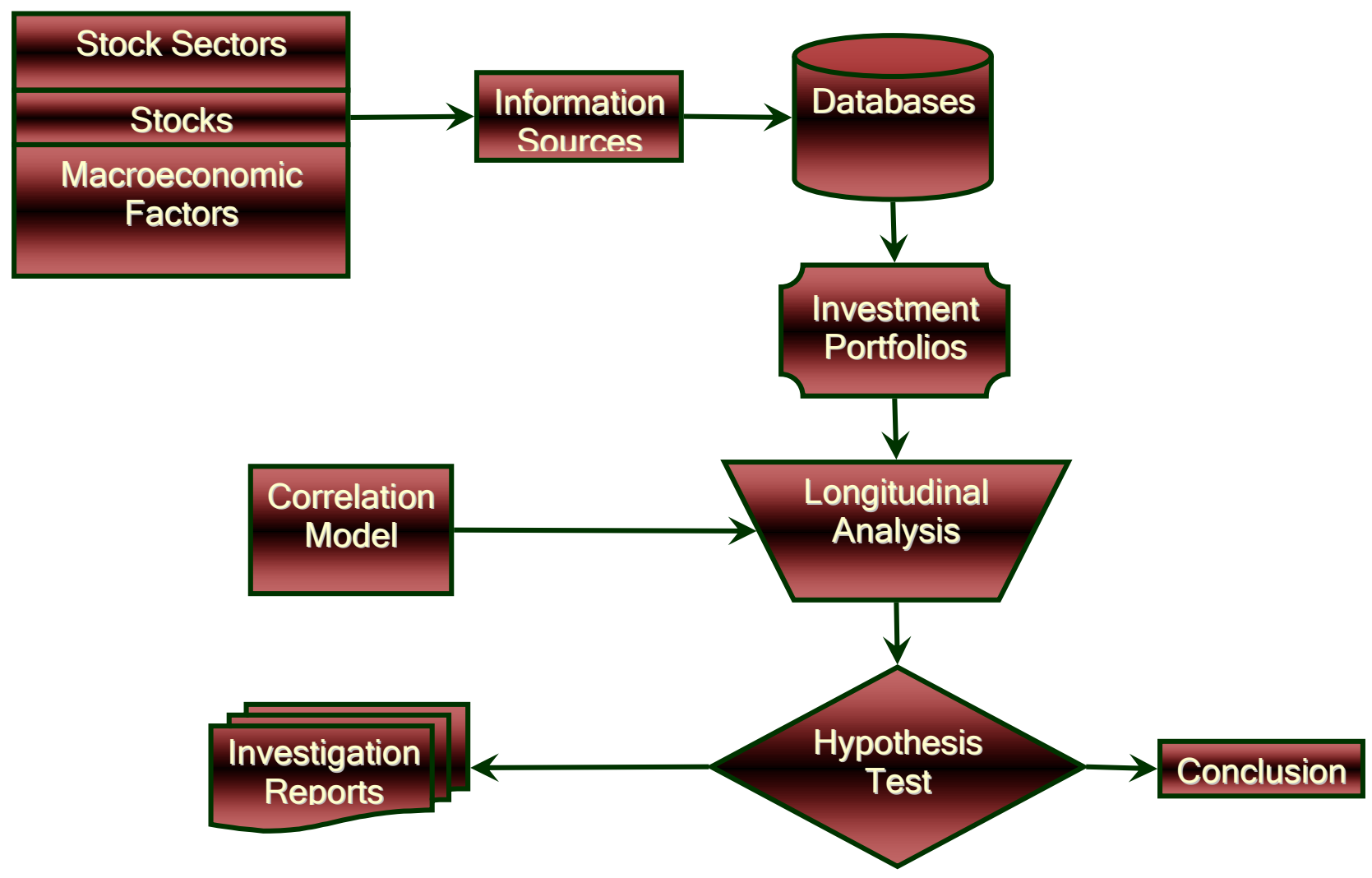

\section{EXPECTED RESULTS}

It is expected that the results of this research will probe the main and secondary hypothesis; it will provide specific data on the macroeconomic variables related to the Mexican stock market performance and will evaluate the impacts of these macroeconomic variables as components of the systematic risk in the different stock market sectors.

This research will benefit the Finance Administration as it will provide scientific elements to explain the impact of macroeconomic variables in the systemic risk of the stock market sectors. 
There will also be an increased effectiveness in the personal and corporate finance decision process as a result of better models and understanding of the stock market mechanics related to specific sectors and economy development. This will also favor higher investment levels in some productive sectors.

The results will help to identify and validate the effects of some macroeconomic variables over the stock market performance, then, more efficient risk measurement models could be established and will allow greater confidence levels to the decision making process in stock market investments.

\section{REFERENCES}

1. Barber Kuri, Carlos Miguel. (2004). La Globalización y el Reto de la Competitividad. En Revista Integra. No. 3 Universidad Anáhuac del Sur. México.

2. Barber Kuri, Carlos Miguel. (2005). Casos Empresariales. Tomo II. Ed. Miguel Ángel Porrúa -UAS. México.

3. Barber Kuri, Carlos Miguel. (2005). Industrias Representativas de América, Europa y Asia. Ed. Miguel Ángel Porrúa-UAS. México.

4. Barber Kuri, Carlos Miguel. (2005). Megatendencias. En Revista Integra. No. 6. Universidad Anáhuac del Sur. México.

5. Baumohl, B. (2005). The Secrets of Economic Indicators. Estados Unidos: Wharton School Publishing. pp. 11-12.

6. Bernoulli, D. (1738). Specimen Theoriae Novae de Mensura Sortis in Commentarii Academiae Scientiarum Imperialis Petropolitannae. Traducción del Latin al Inglés. Sommer, L., Exposition of a New Theory on the Measurement of Risk En Econometrica 22. No. 1. Enero 1954. pp. 23-36.

7. Brealey, R. y Myers, S. (1994). Principios de Finanzas Corporativas. Cuarta Edición. España: McGrawHill, Inc. pp. 170.

8. Burmeister, E., Roll, R. y Ross, S. (2003). Using Macroeconomic Factors to Control Portfolio Risk. En Nota técnica revisada el 9 de Marzo de 2003. pp. 2.

9. Chen, N., Roll R. y Ross, S. (1986). Economic Forces and the Stock Market. En Journal of Business, 59, No. 3. pp. 383-403.

10. Chistian, A. (2000). Métodos de Evaluación del Riesgo para Portafolios de Inversión En Documentos de Trabajo. No. 67. Banco Central de Chile. Marzo 2000.

11. Chu, J., Santoni G. y Liu T. (1996). Stock Market Volatility and Regime Shifts in Returns En Working Paper. Department of Economics. Ball State University.

12. Cramer, J. (2005). Real Money: Sane Investing in an Insane World. Nueva York, Estados Unidos. Simon \& Shuster. pp. 163.

13. Doornik, J. y Ooms, M. (2003). Multimodality in the GARCH Regression Model. En Working Paper. University of Oxford. Octubre 9, 2003.

14. Fallon, W. (1996). Calculating Value-at Risk. The Wharton School, University of Pensilvania. En Wharton Financial Institutions Center's Conference on Risk Management in Banking. Octubre 13-15, 1996. pp. 4.

15. Fama, E. y French, K. (1993). Common Risk Factors in the Returns on Stocks and Bonds. En Journal of Financial Economics. Vol. 33, No. 1. Febrero 1993. University of Chicago. pp. 3-56.

16. Fama, E. y French, K. (2004). The Capital Asset Pricing Model: Theory and Evidence. En Journal of Financial Economics. Vol. 33, No. 1. Febrero 1993. University of Chicago.

17. Frank, F., Modigliani, F. y Ferri, M. (1996). Mercados e Instituciones Financieras. Traducción. Primera Edición Hispanoamericana. México: Prentice Hall.

18. Fraser, N. y Groenewold, N. (1997). Share Prices and Macroeconomic Factors. En Journal of Economic Perspectives. Volumen 18, Numero 3. Verano 2004. pp. 25-46

19. Gouriernox, C. y Monfort, A. (2003). The Econometrics of Efficient Portfolios. En Journal of Empirical Finance. No. 12. ELSEVIER. Julio 21, 2003. pp. 1-41

20. Graham, B. (2003). The Intelligent Investor. Edición Revisada. Nueva York, Estados Unidos: Harper Collins Publishers. pp.157.

21. Herández, R., Fernández, C. y Baptista, P. (2003). Metodología de la Investigación. $3^{\text {a }}$ Edición. México: McGraw Hill. 
22. Johnson, C. Value at Risk: Teoría y Aplicaciones. En Estudios de Economía. Vol. 28 - No 2, Diciembre 2001. Banco Central de Chile. pp. 217-247

23. Khalfani, L. (2004). Investing Success. New Jersey, Estados Unidos: Advantage World Press. pp. 99.

24. Kiyosaki, R. (2000). Guide to Investing. Nueva York, Estados Unidos: The Warner Book Group. pp.142.

25. López, F. y Vázquez, F. (2002). Un Modelo de la APT en la Selección de Portafolios Accionarios en el Mercado Bursátil Mexicano En Revista Contaduría y Administración No. 206, UNAM. Julio, Septiembre 2002. pp. 12, 28.

26. Markowitz, H. M. (1959). Portfolio Selection: Efficient Diversification of Investments. En CC/Numero 36. Rand Corporation. Santa Mónica, California. Septiembre 7, 1992. pp. 1.

27. Mauldin, J. (2004). Bull's Eye Investing, John Wiley \& Sons, Inc., New Jersey, Estados Unidos, pp. 370.

28. Parness, M. (2002). Rule the Freakin' Markets, St. Martin's press, Nueva York, Estados Unidos, pp. 71.

29. Pesaran, H, Zaffaroni, P. (2004). Model Averaging and Value-At-Risk Based Evaluation of Large Multi Asset Volatility Models for Risk Management. En Working Paper. CESifo No. 1358. University of Cambridge. Diciembre 2004.

30. Peters, J. (2001). Estimating and forecasting volatility of stock indices using asymmetric GARCH models and (Skewed) Student-t densities. En Working Paper, Ecole d'Administration des Affaires. University of Li`ege. Belgium. pp. 2-6.

31. Pring, M. (2002). Technical Analysis Explained, Cuarta Edición, McGraw-Hill, Inc., Nueva York, Estados Unidos, pp. 170.

32. Rivas, M. y Díaz, M. (2003). Manual de Metodología de la Investigación I. Colección Sócrates. México: Universidad Anáhuac del Sur.

33. Rivas, M. y Díaz, M. (2003). Manual de Metodología de la Investigación II Colección Sócrates. México: Universidad Anáhuac del Sur.

34. Ross, S. (1976). Arbitrage Theory of Capital Asset Pricing. En Journal of Economic

35. Shiller, R. (2003). The New Financial Order, Risk in the 21st. Century. Oxfordshire, Gran Bretaña: Princeton University Press. pp. 59.

36. Siegel, J. (2002). Stocks for the long Run Nueva York, Estados Unidos: McGraw-Hill, Inc. pp. 231. Theory 13. 